\title{
Professora alfabetizadora: um ofício e muitos fazeres
}

\author{
Liane Castro de Araujo*
}

Mary de Andrade Arapiraca**

Dinéa Maria Sobral Muniz***

\section{Resumo}

Neste artigo discute-se o ofício da professora alfabetizadora de crianças - assumindo o gênero feminino nele predominante - como aquele que envolve um saberfazer relacionado a saberes diversos, vinculados às diferentes facetas do objeto de conhecimento: a língua escrita. Nesse ofício, importa considerar tanto as concepçôes de linguagem, de ensino e aprendizagem, quanto a dimensão sociocultural mais ampla do trânsito no universo da literatura, da tradição oral, da cultura lúdica infantil e dos diversos gêneros discursivos envolvidos nas práticas de leitura e escrita - aspectos fundamentais no âmbito de uma concepção de alfabetização em contexto de letramento, de múltiplos letramentos. Finalmente, articula-se esse ofício de muitos fazeres e saberes a uma formação docente crítica e reflexiva, que assegure às alfabetizadoras a autonomia e a autoria no seu saber e saber-fazer.

Palavras-chave: Alfabetização. Letramento. Formação docente.

* Doutora em Educação pela Universidade Federal da Bahia (UFBA). Professora da Faculdade de Educação da Universidade Federal da Bahia (UFBA).

** Doutora em Educaçáo pela Universidade Federal da Bahia (UFBA). Professora da Faculdade de Educação e da Pós-graduação em Educação da Universidade Federal da Bahia (UFBA).

*** Doutora em Educaçáo pela Universidade Federal da Bahia (UFBA). Professora da Faculdade de Educação e da Pós-graduação em Educação da Universidade Federal da Bahia (UFBA). 


\section{Considerações iniciais}

Para discorrer sobre o ofício de alfabetizar, assumimos singularizar o tratamento no gênero feminino, visto que a história da alfabetização no Brasil tem na mulher professora alfabetizadora protagonismo quase absoluto. Partiremos do pressuposto básico de que a formação da professora alfabetizadora deve, em primeiro lugar, reconhecer o fato de que, mediando as práticas alfabetizadoras, na sala de aula, sempre há uma pessoa - a professora - com seus saberes, afetos, suas experiências diversas com a cultura escrita, inclusive com suas relaçóes com o mundo hodierno afetado por aparelhos eletrônicos, que radicalmente o diferencia de passado bem recente. Professora com concepçóes sobre ensino e sobre aprendizagem da língua escrita, ativando compreensáo responsiva ativa - segundo o conceito bakhtiniano - que lhe permite algum espaço de autoria em sua prática. O fato de a açáo educativa pautar-se em uma relaçáo entre pessoas nos permite assumir que qualquer prática, sustentada por qualquer concepção de alfabetização, é atravessada por essa relação. Até porque, ocupando-se primordialmente da relaçáo da pessoa com o objeto de conhecimento, o ato educativo tem implícito o fazer inalienável de quem nele está implicado, mesmo que, ao outro, pareça que são movimentos aleatórios.

Assim, se há, nas memórias do processo de alfabetização de educadores e escritores, aquelas experiências relacionadas à práticas mecânicas repetitivas, descontextualizadas, há também aquelas que são marcadas por muita afetividade e, algumas vezes - porque as professoras têm também suas autorias -, marcadas igualmente pela inserção em práticas letradas, especialmente a literatura - independentemente do método usado para a alfabetização. Como bem expressou Bartolomeu Campos de Queirós (2004, p. 34), referindo-se à professora alfabetizadora Dona Maria ao ensinar-lhes as letras: "ninguém tinha maior e melhor sabedoria, mais encanto [...]. O giz, em sua mão, mais parecia um pedaço de varinha mágica de fada, explicando os mistérios".

Professoras de ontem deixaram suas marcas na vida de alunas que são as professoras de hoje, sendo, de algum modo, presenças marcantes incorporadas a suas identidades. Refletindo sobre os segredos e as artes do ofício de professor, Arroyo (2002, p. 18) destaca que "o saber-fazer, as artes dos mestres da educaçáo do passado deixaram suas marcas na prática dos educadores e das educadoras de nossos dias. Esse saber-fazer e suas dimensóes ou traços mais permanentes sobrevivem em todos nós na forma de autoimagens reconstruídas". 
Essa premissa implica no reconhecimento de que a ação educativa vai além dos saberes relativos à área de atuação do professor - e no caso da professora alfabetizadora, o campo do ensino da língua escrita -, ampliando-se no sentido de ressaltar a importância de sua pessoa na sua própria formação. Como discute Tardif (2002), o professor é um docente profissional que, em seu cotidiano, constrói e reconstrói saberes plurais - saberes que articulam os saberes da formaçáo acadêmica com os da prática docente, e mesmo com os ressignificados a partir de suas vivências como alunos que um dia aprenderam a ler e escrever.

A esses saberes acrescentam-se aqueles vinculados à relação dos sujeitos envolvidos na alfabetização com o mundo dos textos e da massa de informaçóes advindas da "sociedade do conhecimento" ou "sociedade da informaçáo". Importa atentar para como tudo isso reverbera no seu fazer e em sua formação. Pensar ou repensar o ofício de alfabetizadora neste "admirável mundo novo" em que vivemos, digitalizado e virtual, exposto a uma permanente explosão de informaçôes em imagens e sons, é uma fonte inesgotável de tensões, considerando que o ato alfabetizador arquiteta uma totalidade que supóe fatores de ordem diversa, desde os mais amplos, econômicos, sócio-históricos e culturais dos sujeitos do ensino e aprendizagem (alfabetizador e alfabetizando), até o objeto de conhecimento implicado diretamente nessa relação, a língua escrita. A escrita como o objeto de conhecimento do processo alfabetizador, nem mesmo em termos instrumentais, se isola do contexto do qual emerge.

\section{Saberes e práticas na formação de professores}

Nessa linha de argumentação, encontramos diálogos com as perspectivas sobre o trabalho docente que consideram os saberes construídos pelas professoras em sua formação, sua voz, suas concepçóes, como Nóvoa (1992, 1995), Tardif (2002), dentre outros, lançando a essa discussão também a ideia das professoras como sujeitos que se movem nos discursos a partir de sua compreensão responsiva ativa, como nos ensina a perspectiva de Bakhtin (1994).

Substituindo um modelo de formação de professores fundamentado em uma racionalidade técnica, que enfatizava a apropriação de saberes instrumentais e tomava a prática como uma aplicação de conhecimentos técnico-pedagógicos, tem-se, especialmente com Schön (2000), um outro modelo que se fundamenta sobre uma espécie de racionalidade prática, que considera o professor como um 
profissional autônomo, reflexivo, que toma decisóes e cria soluçóes para os desafios da prática docente, além de implicado como subjetividade. A prática é então vista como espaço de criação e reflexão em que os conhecimentos, de naturezas diversas, são constantemente gerados, modificados e mobilizados. E é vista também como uma prática complexa que envolve saberes diversos, que articulam teoria e prática, saber e saber-fazer e, podemos ainda complementar, implica sujeitos, sujeitos de conhecimento, sujeitos de linguagem, sujeitos de história, de cultura. Com Bakhtin (1994), podemos dizer igualmente - no âmbito de um posicionamento sobre a constituição de discursos, saberes, sujeitos, linguagem e autoria - sujeitos constituídos dialogicamente, implicados em uma compreensão responsiva dos discursos, que supõe uma formulação ativa de resposta, de "contrapalavras". No plano da responsividade, o ser humano é um ser de resposta.

Nossa "palavra" - nossa enunciação, nosso discurso, nossa consciência - no âmbito do dialogismo de Bakhtin (1981), está repleta das palavras do outro, e é caracterizada, em graus diferentes de alteridade e apropriação, por um emprego que vai do idêntico ou plagiado, ao retrabalhado, modulado ou inflexionado dessas "palavras alheias". A voz de um indivíduo, seu discurso, é constituída da apropriaçáo criativa e/ou assujeitada de palavras múltiplas do outro, dos outros, que ele incorpora, transforma, recusa, rebate, confronta, modifica, assimila. A experiência discursiva individual se faz nessa interaçáo. As "palavras alheias" se tornam "pessoais", "próprias", pois, no rearranjo dos significados, cada um se constitui como sujeito de seu discurso. Na situação concreta, dialógica, cada um instaura a autoria de sua palavra, constitui-se como sujeito de linguagem, havendo o lugar para a autoria em meio às tantas vozes que constituem o nosso discurso próprio. Assim, pelo viés dessa perspectiva, podemos também caracterizar os saberes docentes como saberes construídos dialogicamente, nessa multiplicidade de vozes, na qual se constitui também a voz própria dos professores.

A perspectiva bakhtiniana pode, assim, dialogar com as posições de diversos autores da área da formação de professores, contribuindo para pensarmos a questão dos saberes docentes na formação de alfabetizadoras, em termos dos diálogos que esses estabelecem com os saberes acadêmicos - vozes dos campos diversos do conhecimento - e os diálogos entre a vida de quem é professor e a sua profissão, seu ofício.

A teoria e a ação educativas como duas vertentes indissociáveis, a legitimação das teorias geradas na e pela ação docente e o papel dos saberes do 
próprio fazer são aspectos que têm sido enfatizados nas perspectivas atuais de formação de professores, que ressaltam a importância de se considerar e valorizar a prática pedagógica e os saberes advindos dessa prática como fontes de sua formaçáo, pois permitem que construam e (re)construam outros, assim como reelaborem os conhecimentos acadêmicos iniciais. Importa, ainda, associar os saberes próprios da docência, aqueloutros advindos da própria prática de vida, que incluem e transpassam a prática docente.

Schön $(1992,2000)$ discute sobre a epistemologia da prática, o professor como profissional reflexivo e a dinâmica da reflexão na ação e reflexão sobre a ação, na formação do professor; Nóvoa (1995) enfatiza a voz e a história de vida de professores, aspecto enfatizado também por outros autores, a exemplo de Arroyo (2002), que argumenta sobre como a vida se mistura com a condição de professor e como isso tem implicações na sua formação.

Tal como ressaltado por esses e outros diversos autores, é preciso lembrar que, considerar o saber dos professores, não significa minimizar os conhecimentos de que precisam se apropriar sobre o ensino, sobre a aprendizagem, sobre o objeto de conhecimento e, finalmente, sobre os conhecimentos pedagógicos e culturais mais amplos. A articulação entre teoria e prática se constitui como um dos princípios e fundamentos para a formação do professor, e como núcleo integrador dessa formação, sendo concebida como unidade indissociável. A educação é uma prática, mas uma prática intencionada pela teoria, como nos ensina Pimenta e Lima (2011). Por isso mesmo, defender a autoria da professora alfabetizadora em relaçấo a sua prática não se confunde com defender que a opção metodológica da professora é que vale, seja qual for. Ao considerar a formação como um espaço de articulação de saberes diversos e, no caso do ensino da língua escrita - um objeto de conhecimento e de ensino que exige, em si mesmo, a articulaçáo de vários saberes -, é preciso assegurar o direito a uma formação plena, de muitos conhecimentos entrelaçados, vozes diversas vindas de diversos campos do conhecimento que contribuem para constituir uma concepçáo de alfabetização, ao lado da valorização da docência profissional do professor alfabetizador.

Como ressaltam Fiorentini, Souza Júnior e Melo (1998), os saberes valorizados na formação de professores na década sessenta referiam-se aos saberes específicos sobre os conteúdos da disciplina em questáo, a ênfase recaindo no objeto de conhecimento. A partir da década de setenta essa valorizaçáo deslocase para os aspectos teórico-metodológicos do ensino que, no campo do ensino 
da língua escrita, já era uma preocupação que acompanhou todo o processo de estabelecimento dos diversos métodos de alfabetização no Brasil. Nos anos oitenta, o discurso sobre formação de professores é dominado pela dimensão sociopolítica da prática pedagógica.

No âmbito do ensino da língua, há, a partir dos anos oitenta, uma mudança considerável de concepção de alfabetização e esse campo passa a acolher diversas contribuiçóes de campos diversos, que culmina, hoje, com uma concepção de alfabetização em contexto de letramento, envolvendo diversos aspectos e facetas. Com isso, a formação de professoras alfabetizadoras vem continuamente tornando-se uma exigência, efetivando-se gradativamente, e a criação de uma política pública responsável de formação, que considere a complexidade do processo de alfabetização, precisa se consolidar, para construirmos uma docência de responsabilidade e responsividade no campo da linguagem e da apropriação inicial da língua escrita.

$\mathrm{Na}$ visão de Schön (2000), longe de uma perspectiva de formação de professores pautada numa racionalidade técnica que tomava a teoria e a prática de modo dicotomizado, separado, e na crença de que para ser um bom professor bastaria ter um domínio da área de conhecimento específica que irá ensinar, exige-se hoje uma racionalidade prática e crítica, que implica uma constante reflexão sobre a prática. $\mathrm{Na}$ formação continuada, essa reflexão se dá desafiando a reelaboração dos saberes profissionais da formação acadêmica pela experiência vivenciada na escola e, na formação inicial, especialmente nos espaços de estágio curricular supervisionado ou programas de iniciação à docência.

Essa mudança de paradigma diferencia o professor de um profissional técnico, mero repetidor e aplicador de conhecimentos construídos por outros, colocando-o como protagonista na construção dos saberes sobre sua prática, no diálogo com os conhecimentos diversos construídos em torno do seu campo de atuação. É justamente munido de conhecimentos diversos que o professor se qualifica e se torna capaz de refletir sobre sua prática, levantar questóes sobre ela e buscar soluçóes, enfrentando os desafios postos pela profissão docente.

Tendo, no contexto de sua formação e atuação, esse tipo de participaçáo ativa, a alfabetizadora garante sua voz na construção de seu ofício e, movendo-se entre as palavras alheias e as palavras próprias, apropriadas, elabora sua compreensão responsiva ativa sobre o campo da educação, da alfabetização. 


\section{Os saberes do ofício de alfabetizar}

Além de conhecimentos mais amplos de cunho pedagógico e sociopolítico, é preciso que aquela que alfabetiza - como todo professor - articule conhecimentos de diversas naturezas em sua prática. O seu fazer, bem como a sua formação, assenta-se em um tripé formado por eixos que dizem respeito aos saberes sobre o ensino, sobre a aprendizagem e sobre o objeto de conhecimento em questáo. E esses saberes são compostos, como já discutido, não apenas dos conhecimentos teórico-metodológicos, mas dos saberes práticos e das experiências pessoais vividas pelos professores em sua formação e docência, das concepções de ensino, aprendizagem, linguagem e alfabetização que vão construindo nesse fazer-se alfabetizador. E articulado a todos esses aspectos, é preciso ainda agregar conhecimentos advindos de uma dimensão cultural mais ampla, que diz respeito às próprias experiências culturais do sujeito que tem a docência como profissão.

Historicamente a alfabetização foi considerada por muito tempo como o ensino da língua escrita como um código de transcriçâo da fala a ser memorizado. Assim, nessa ótica, a preocupação maior quanto à alfabetização era focalizada no eixo do ensino: a questão maior que balizava as práticas de alfabetização era relativa aos métodos que seriam mais adequados para alfabetizar. Acreditava-se que, uma vez que o professor seguisse as orientaçóes metodológicas, ou seja, o passo a passo colocado nas cartilhas, a aprendizagem de todos seria garantida, já que a aprendizagem era vista como um acúmulo de informaçôes adquiridas de modo mais ou menos passivo pelo sujeito que aprende. As questóes de aprendizagem de uns e de outros, que eventualmente não acompanhassem os passos do estudo, eram vistas como dificuldades do próprio sujeito. Essa perspectiva colocava em cena, muitas vezes, a professora como uma profissional técnica, a quem cabia aplicar passos pré-definidos pelos métodos - aspecto presente ainda hoje em algumas perspectivas de sistemas de ensino, que deixam pouco espaço para a autonomia da professora em construir a sua prática. Ainda que a pessoa - a pessoa da professora - sempre se desponte ali no seu cotidiano com suas crianças, e que, apesar dos métodos e concepções subjacentes às propostas educativas, insista aqui e ali em trazer elementos outros para essa interação educativa, esse não era um foco na sua formação, na sua ação. O foco era técnico, no ensino, no método.

A partir da concepçâo construtivista de aprendizagem, com as formulaçôes de Piaget, passa-se a enfatizar o eixo da aprendizagem, o como o sujeito aprende 
sobre o objeto de conhecimento e a sua construção ativa de conhecimentos. $\mathrm{O}$ foco das reflexóes no campo da alfabetização, que antes recaia no ensino, no como ensinar, por qual método ensinar, e numa visão adultocêntrica sobre o que seria fácil e difícil, simples e complexo ao se organizar o trabalho pedagógico, passa a ser a construçấo do sistema de escrita pelo sujeito.

As pesquisas de Ferreiro e Teberosky (1986) sobre a psicogênese da língua escrita, de filiação epistemológica piagetiana, demonstraram que, para aprender como o sistema de escrita funciona, o sujeito, desde que em contato com a escrita alfabética, vive um processo construtivo, um trabalho conceitual, pensando e criando hipóteses para entender o que é a escrita e como ela funciona, mesmo antes de descobrir que a escrita tem relação com a pauta sonora da língua. $\mathrm{O}$ objeto de conhecimento, e o que é simples ou complexo em relação a ele, passa a ser visto pela perspectiva desse sujeito que aprende.

Assim, a partir dos anos 1980, a alfabetização passou a ser concebida como um processo ativo por meio do qual a criança, desde seus primeiros contatos com a escrita, constrói e reconstrói hipóteses sobre a natureza e o funcionamento do sistema alfabético. A escrita alfabética é compreendida aí como um sistema de notação da linguagem oral, e não um código de transcrição da fala, com relaçōes substitutivas diretas, biunívocas, entre signos. Havia aí, também, uma preocupação de que esse contato com a escrita fosse a partir dos seus usos reais e autênticos, em situaçóes significativas, de leitura e produção de sentido.

A perspectiva sociointeracionista, por sua vez, veio enfatizar o aspecto sociocultural e histórico da aprendizagem, argumentando que a aprendizagem não se dá apenas na relação do sujeito com o objeto de conhecimento, mas nas suas interaçóes com os outros, com a cultura. A importância da mediação do outro - do professor, dos pares - na aprendizagem é ressaltada. Atuando na zona de desenvolvimento proximal das crianças, conforme conceito de Vygotsky (1984), o professor favorece os avanços na construção dos conhecimentos. Enfatizando a importância da dimensão sociocultural da aprendizagem, essa perspectiva garante ao ensino um papel no processo de apropriaçáo de objetos culturais, construídos socialmente, como é o caso da escrita alfabética.

Do mesmo modo que Ferreiro (2001) discute, no âmbito de suas formulaçóes sobre a construção da escrita alfabética pelas crianças, sobre a importância de que essa aprendizagem se dê no contexto de usos reais da escrita, Vygotsky (1984) enfatizava, já na década de trinta do século passado, a importância de que a escrita fosse ensinada como uma atividade cultural 
complexa, significativa, e não como uma habilidade perceptiva e motora embora esse posicionamento do autor só tenha chegado até nós na década de oitenta. É a partir dessa década referida que essa questáo ganha força, especialmente com os estudos sobre letramento, os quais, de modo contundente, passam a conceber a escrita, antes de tudo, como uma prática sociocultural e não um simples sistema notacional.

A discussão em torno da necessidade de letrar e não somente alfabetizar, para que os sujeitos possam usar o sistema de escrita com autonomia e participar das práticas letradas na sociedade, determinou um ensino centrado nos textos que usamos nas diferentes práticas sociais de linguagem, que sempre pertencem a gêneros adequados a cada situação comunicativa. Os usos da escrita são enfatizados e a leitura e produção de sentidos é o foco do trabalho de apropriação da escrita. As perspectivas bakhtiniana sobre os gêneros discursivos e sobre a concepção de linguagem como interação, aliadas aos estudos sobre letramento, desenvolvidos no Brasil, especialmente por Kleiman (1995), Tfouni (1995), Soares (2001), Rojo (1998), dentre outros, foram fundamentais nessa nova orientação da prática educativa.

Ultrapassando a velha querela dos métodos de alfabetização, centrados na faceta linguística da alfabetização, e esvaziando a questão de qual seria o melhor deles para alfabetizar - já que nenhum deles, analíticos ou sintéticos, ocupam-se das dimensóes psicológica e sociocultural referidas -, esses campos trouxeram mudanças fundamentais no modo de conceber a alfabetizaçáo. $\mathrm{O}$ sujeito que aprende e seus processos de construção de conhecimento passaram a ser considerados no ensino, o papel das interaçóes sociais foi ressaltado na aprendizagem e a dimensão discursiva da escrita foi amplamente enfatizada. Com isso, se por um lado os processos de análise e síntese continuam existindo como operaçôes cognitivas em torno da apropriaçáo da escrita, já não fazem mais sentido como método prescritivo, exclusivo e reducionista de aproximação do sistema alfabético.

A ênfase na faceta psicológica da alfabetização - com as formulaçôes construtivistas e sociointeracionistas - teve o mérito de possibilitar tomarmos o ensino da escrita a partir de como os sujeitos, de fato, aprendem. Entretanto, junto com ênfase na dimensão do letramento, houve, como enfatiza Soares (2003a), uma espécie de esquecimento da faceta linguística da alfabetização, pela perda do foco na especificidade do processo de apropriação do sistema alfabético. Esse equívoco a autora chamou de "desinvençáo da alfabetização", 
deu-se também devido a inferências equivocadas na transposição da concepção construtivista e do letramento para a prática pedagógica - como a ideia de que o convívio com textos seria suficiente para a alfabetização acontecer, a ideia da incompatibilidade entre a concepçáo construtivista e a questão do método, bem como a ideia de que abordar unidades linguísticas menores que as palavras, seria incompatível com uma abordagem significativa da linguagem, dos textos.

Assim, no apelo à "reinvenção da alfabetização", a autora propõe que se restitua a importância da especificidade do processo de apropriação do sistema de escrita alfabética, enfatizando a faceta linguística da aprendizagem da língua escrita, mas dessa vez em contexto de letramento e considerando como a criança constrói o conhecimento, e não a partir da perspectiva empirista e mecanicista dos métodos tradicionais de alfabetização. Quando Soares (2001) discute a concepção de alfabetizar em contexto de letramento, defende a açáo de ensinar a ler e escrever com autonomia - ou seja, propiciar a apropriação do sistema de escrita alfabética, sua natureza e funcionamento - no contexto das práticas sociais de leitura e escrita da sociedade. Desse modo, a pessoa letrada além de saber ler e escrever, também cultiva e exerce as práticas sociais mediadas pela escrita.

As implicaçóes da articulação entre os conceitos de alfabetização e letramento nos levam, por um lado, a reconhecer a relação cultural, histórica e sociocognitiva - e não meramente instrumental - que estabelecemos com o sistema de escrita alfabética e, por outro lado, a reconhecer a importância da apropriação desse sistema para a autonomia na participação em práticas letradas. Assim, como a língua escrita, no nosso sistema alfabético, nota significantes sonoros - uma cadeia de fonemas - e não os significados das palavras como nos sistemas ideográficos, é necessário prestar atenção à pauta sonora da língua e trabalhar as articulações entre fonemas e grafemas, para aprender a ler e escrever. As açôes didáticas focadas apenas na dimensão sociodiscursiva da linguagem não bastam para apropriar-se desse complexo sistema de escrita.

Se a escrita alfabética é um sistema complexo construído historicamente, cuja aprendizagem exige a compreensão gradual de suas propriedades, é justo e preciso instituir açóes pedagógicas intencionais, para que as crianças, no cotidiano das práticas de alfabetização, se apropriem dele. Ao lado do trabalho com a leitura e escrita em diversos gêneros e do letramento, é, assim, fundamental garantir intervençóes no sentido de favorecer a conquista gradual do nível alfabético (provocar o avanço nas hipóteses de escrita) e, depois, das correspondências grafofônicas. 
E aí está implicado também o trabalho com a consciência fonológica, com e sem a presença da escrita, aspecto que, embora trazido à discussão no campo da alfabetização, principalmente pela psicologia cognitiva da leitura, tem um grande papel nas apropriaçóes que dizem respeito à faceta linguística do ensino e aprendizagem da língua escrita.

Além de provocar a pesquisa inteligente relativa aos aspectos fonológicos e fonográficos da língua, a faceta linguística da alfabetização implica em ampliar, no contexto de práticas lúdicas, contextualizadas e significativas, o conhecimento das letras, signos da escrita no nosso sistema (categorização gráfica e funcional); em favorecer o uso de estratégias várias de reconhecimento de palavras, de leitura, para assegurar o acesso lexical às palavras via acesso fonológico; em favorecer a fluência da leitura de palavras e textos e conhecer gradativamente as particularidades ortográficas do nosso sistema de escrita.

Assim, diante do eixo do conteúdo, do objeto de conhecimento, são inúmeros os saberes a construir. Enfatiza-se aí também que, tanto no nível do discurso quanto no nível do sistema notacional, é preciso compreender as inúmeras articulaçóes entre a linguagem oral e escrita, e mais, também suas relações com outras linguagens, como a linguagem visual e audiovisual. As linguagens oral, escrita, visual, digital são formas distintas de comunicação que apresentam diferentes semióticas, novas formas de discurso, não se excluindo, mas, ao contrário, mesclando-se, interferindo umas nas outras de forma complexa, criando híbridos.

A heterogeneidade e hibridismo das linguagens e dos textos na contemporaneidade, assim favorecidos pelos novos suportes dos textos, exigem uma competência marcadamente contemporânea para conceber "entre-lugares", flexibilidade em categorizaçóes, enunciaçóes mais instáveis e experiências mais versáteis em relação às linguagens. E exigem de professores e alunos, como usuários, uma reorganização de suas experiências de linguagem, uma ampliação constante de sua versatilidade em lidar com diversos gêneros, suportes, modos de ler e de ser letrado. Como bem coloca Ribeiro (2007, p. 132), "os passos dados da tabuleta de cera em direção à tela foram lentos, graduais e perfeitamente integrados a uma experiência de versatilidade e não de exclusividade".

É exigente o ofício da alfabetizadora, que comporta uma gama de compreensôes sobre o objeto de conhecimento, seja acerca da escrita como prática social ou como sistema de notação, seja acerca do como a aprendizagem ocorre, no nível conceitual e interativo, relativo às experiências com a linguagem 
escrita, com os textos, com os gêneros. É preciso articular saberes do campo da linguagem e da psicologia do desenvolvimento e da aprendizagem, saber como o sistema de escrita funciona e como a linguagem escrita se apresenta em diversos gêneros de texto e, do ponto de vista da aprendizagem, como as crianças se apropriam desses conhecimentos.

A partir dessas concepçôes e conhecimentos a respeito dos conteúdos e da aprendizagem é que os fazeres da alfabetizadora se organizam, de modo a incluir todas as facetas da alfabetização e do letramento. E nesse ponto está em jogo discussóes de ordem metodológica, o que implica em organizar práticas educativas para abordar esse objeto que é complexo e que exige uma série de operaçóes cognitivas para ser aprendido, a partir de uma metodologia de reflexão intencional, sistemática e em progressão sobre a língua e a linguagem. Assim, no eixo do ensino, além de articular saberes mais amplos sobre currículo, planejamento, didática, avaliação, o professor articula em seus muitos fazeres na prática cotidiana, diversas facetas, eixos, dimensões e aspectos do ensino da língua em objetivos, conteúdos, materiais e propostas, numa perspectiva de progressão das aprendizagens, a partir de um diagnóstico da turma e dos alunos em particular, considerando inclusive e especialmente a heterogeneidade do grupo.

A aprendizagem da língua escrita tem muitas facetas - como ressalta Soares (2003b) -, que demandam intervençōes específicas, mas que precisam ser integradas e articuladas na prática pedagógica. $\mathrm{O}$ ensino precisa considerar tudo isso. Não são poucos, portanto, os saberes e fazeres do ofício de uma professora alfabetizadora!

Além desses três eixos - o objeto de conhecimento, a aprendizagem e o ensino -, ao professor alfabetizador não é permitido se abster de um repertório cultural mais amplo que lhe permita oferecer situaçóes ricas de aprendizagens sobre a língua e a linguagem. Os seus muitos fazeres na sala de aula de alfabetização estarão permeados desses saberes de ordem cultural, relativos, em especial, às culturas da infância. Essa dimensão cultural mais ampla é que vai lhe permitir transitar no universo da literatura, da tradição oral, da cultura lúdica infantil, bem como dos diversos gêneros discursivos envolvidos em práticas de leitura e escrita do universo sociocultural em que as crianças se inserem - aspectos fundamentais no âmbito de uma concepção de alfabetização em contexto de letramento.

Dessa forma, é importante que essa professora tenha familiaridade com a literatura infantil, os textos da tradição oral, os jogos de linguagem, funções 
e características de diferentes gêneros que circulam socialmente. Ser leitora dessa literatura, conhecer os livros, encantar-se com eles, familiarizar-se com a linguagem poética e narrativa, poder observar as peculiaridades da leitura das imagens nesses livros, são desafios que se impóem a quem lida com esse segmento, para que possa oferecer a literatura às crianças e ser, de fato, uma facilitadora da interaçáo delas com o universo literário.

Do mesmo modo, importa igualmente, conhecer a cultura infantil, a tradição oral e seus muitos textos narrativos e poéticos, para poder disponibilizar e trabalhar com esse repertório cultural e com a brincadeira com a linguagem, fundamental para o desenvolvimento da oralidade e da consciência fonológica. A poesia oral apresenta um repertório altamente privilegiado para a reflexão sobre os aspectos sonoros da linguagem, favorecendo, também, quando apresentada por escrito, o reconhecimento de palavras e a pesquisa inteligente e significativa sobre o sistema alfabético, pelos ajustes que as crianças precisaráo fazer entre a pauta sonora, que sabem de cor, e o registro gráfico dos textos, em suas tentativas de ler sem ainda saber fazê-lo.

Como não enfatizar também o sentido altamente positivo de a professora alfabetizadora conhecer jogos de linguagem, para compreender as reflexóes linguísticas e metalinguísticas que eles favorecem, e assim poder incluí-los intencionalmente como recurso importantíssimo de reflexão sobre a língua, pela criança, seja sobre sua pauta sonora ou desta em interface com a escrita. Compreendendo os processos postos nos jogos, as unidades que trabalham, poderá refletir sobre as intervençôes que provoquem os avanços das crianças em suas hipóteses e conhecimentos.

É importante, para quem alfabetiza, conhecer, ainda, diversos gêneros de textos usados nas diversas práticas sociais, suas funções, usos e características, equilibrando um saber metalinguístico sobre esses gêneros ao uso efetivo, significativo e justificável em sala de aula, selecionando as situaçôes adequadas de abordá-los, para que não resulte em um mero aprendizado de características desvinculadas de suas reais necessidades de uso. Nesse sentido, cabe-lhe desenvolver um olhar atento para os eventos de letramento em que seus alunos se envolvem e aqueles do contexto cultural mais amplo.

E dentre esses eventos de letramento, possivelmente haverá também aqueles relacionados às práticas de leitura e escrita nas telas de dispositivos tecnológicos diversos, que se apresentam como artefatos e como linguagem. Assim, nesse âmbito dos saberes docentes relativos a um contexto cultural mais 
amplo, inserem-se também as experiências com a escrita e a leitura de novos gêneros, seus hibridismos, em novos suportes, a partir de novos gestos de leitura e escrita e novas interações com as diversas linguagens.

Dessa forma, é preciso considerar a discussão sobre alfabetização e letramento e também em seus desdobramentos na contemporaneidade. A própria Soares (2002) explora duas facetas da alfabetização na cibercultura: uma relacionada aos espaços da escrita e suas consequências para a interação entre autor/leitor e outra relacionada aos gêneros, às novas formas de produção, reprodução e circulação dos textos.

Tudo isso significa que, se pensarmos em um sentido mais amplo do letramento, envolvendo as noçóes de letramentos múltiplos e multiletramentos, conforme discutem Rojo (2009) e Rojo e Moura (2012), às professoras alfabetizadoras - mas não apenas a essas - compete, ainda, conhecer a multiplicidade e variedade de práticas letradas reconhecidas ou não pelas sociedades, as práticas culturais de linguagens diversas que dialogam com a linguagem escrita, as produçóes culturais que se apresentam, hoje, como um conjunto de textos híbridos de diferentes gêneros, ligados ou não às tecnologias de comunicação e informação. Gêneros que circulam nas comunidades em que seus alunos se inserem, gêneros marginalizados, geralmente não legitimados pela escola, mas socialmente muito presentes como práticas de letramento "de resistência”, conforme ressalta Rojo (2009), parte desses múltiplos letramentos que devem poder dialogar com os letramentos dominantes.

Se a sociedade hoje funciona a partir de uma diversidade de linguagens, de mídias e de culturas - e as culturas infantis também participam desse movimento - não tem como o professor ficar alheio às discussóes e práticas que envolvem multiletramentos, multilinguagens, multiculturas. É preciso, nesse sentido, ampliar a noção de letramento para que possa abarcar diversos modos de ser letrado, os diferentes modos de inserção e de uso da escrita contemporaneamente.

$\mathrm{Na}$ medida em que tornam seus esses repertórios - seja como saberes culturais pessoais ou como saberes cultivados por serem necessários à docência-, fazendo-os dialogar com seus próprios repertórios culturais, as professoras, possivelmente, tornam-se mais hábeis para, de fato, estabelecer verdadeiras interaçóes com as crianças em relação a eles e promover interaçóes ricas entre elas e esses repertórios, evitando apresentá-los pontualmente e artificialmente em situações didáticas específicas. 
Ao lado dessa dimensão cultural há ainda que argumentar sobre a dimensão sociopolítica da formação do docente responsável pela alfabetização e pelo letramento. É um grande desafio conhecer os usos da leitura e da escrita das camadas sociais que estão nas escolas públicas, muitos deles não legitimados pela instituiçâo escolar, para efetivar o ensino da leitura e da escrita na perspectiva dos letramentos múltiplos, garantindo que o direito à alfabetizaçáo e ao letramento seja acompanhado pelo reconhecimento desses usos e, ao mesmo tempo, pela democratizaçáo e ampliaçáo das práticas diversas de uso da escrita pelas classes populares, permitindo-lhes ultrapassarem fronteiras traçadas como destino por sua condiçâo na sociedade.

Considerando tudo o que foi discutido, podemos concluir que, além do acesso aos conhecimentos sobre os aspectos e facetas que dizem respeito ao campo de atuação da professora alfabetizadora, trata-se de ampliar a visão de formação dessa profissional para uma formação que é para um ofício, um ofício de muitos saberes e fazeres, resgatando a dimensão cultural da educaçáo, em que as professoras se reconheçam na cultura, produzam cultura, formem crianças para a participação no universo sociocultural - que inclui o uso da linguagem escrita e a participaçáo cada vez mais ampla nas práticas letradas de seu meio.

\section{Palavras finais}

Como forma de concluir este texto, optamos por abordar uma categoria que congrega grande parte de nossa discussão anterior: a democratização do acesso à leitura e à escrita para crianças de seis anos e mais que frequentam nossas escolas, em especial as escolas públicas, sem descuidar daquelas que frequentam a Educação Infantil, espaço no qual a democratização teria início com o acesso à cultura escrita nos anos iniciais.

Como democratizar? No nosso entendimento, o processo de democratização envolve vários âmbitos de competências. Existe o âmbito das competências governamentais, que inclui as esferas Federal, Estadual e Municipal. Sincronizar o funcionamento dessas esferas, a partir das demandas sociais, no caso específico da alfabetização, é um desafio que temos que enfrentar com determinação política. Outro âmbito de competência é o das unidades escolares, como espaços em que os programas de alfabetização se concretizam ou se processam. Não podemos mais aceitar passivamente que seja subtraída das unidades escolares, em especial das salas de aula, a 
responsabilidade pela condução e pelo sucesso da alfabetização de crianças. Para tanto, cabe considerar o ofício da professora alfabetizadora como um conjunto complexo de fazeres de qualidade, voltado de forma efetiva para as necessidades de inserção de grande contingente de nossas crianças escolarizadas no mundo letrado.

Existe outro âmbito de competência que se traduz nos espaços em que os programas de alfabetização se concretizam, se processam, que são os das unidades escolares. Não podemos mais aceitar passivamente que seja subtraída das unidades escolares, em especial das salas de aula, a responsabilidade pelo sucesso da alfabetização de crianças. Desse modo, cabe considerar esse ofício como dotado de fazeres de qualidade, voltados de forma efetiva para as necessidades de inserçáo no mundo letrado por parte de grande contingente de nossas crianças escolarizadas.

Se concebermos que formar sujeitos leitores e produtores de textos é formar para a participação sociocultural, se compreendermos que a linguagem dos alunos é o meio pelo qual podem se colocar no mundo com suas palavras próprias - no sentido bakhtiniano da expressão -, então formar os formadores desses sujeitos implica também em considerar suas vozes próprias, assegurandolhes autonomia e autoria no seu saber e saber-fazer.

Por outro lado, as professoras em exercício de seu ofício ou em formação têm suas próprias ideias e concepçóes sobre o ensino, sobre como os alunos aprendem e sobre a natureza e epistemologia dos conteúdos a serem aprendidos/ ensinados. Em situação de formação, inicial ou continuada, é necessário mobilizar essas concepções, pois elas têm grande papel nas práticas docentes e nas açóes pedagógicas de professoras alfabetizadoras, que agregam saberes diversos, por vezes dispersos, advindos de concepçóes diferentes e mesmo contraditórias. É esse o grande espaço de diálogo, na perspectiva que as práticas ultrapassem o senso comum. O exercício de duvidar do empírico imediato, desvelar os reais significados das práticas, significá-las, ressignificá-las, dialogar com elas, tomá-las criticamente como objeto de reflexão, transformá-las, é o substantivo dos processos de formação de professores.

As argumentaçóes sobre o ofício da professora alfabetizadora fundamentam-se aqui em uma concepçáo de linguagem e de sujeito que requer uma abordagem da construção do conhecimento e da formação em sua dimensão polissêmica e polifônica, na qual o professor se afirma como produtor cultural, social e histórico de suas açóes docentes, interagindo com 
o contexto dialógico de seu tempo, ser de resposta e de responsabilidade, de palavras e contrapalavras, não mero repetidor de palavras alheias, não apropriadas.

Se, por um lado, a vida do profissional é, antes de qualquer coisa, a vida da pessoa que trabalha como professor, como ressalta Nóvoa (1995), o professor deve exercer seu ofício profissionalmente, e um profissional precisa dialogar a partir de seu ofício, de sua prática, e debater, discutir e se posicionar, a partir de seu ofício, com argumentos, com conhecimento de causa, vindo de seu saber e seu saber fazer, que articulam estudos de campos de conhecimentos diversos a sua vivência como professora.

Assim, faz parte da busca por uma escola pública de qualidade, com cada vez mais leitores e escritores dialogando a partir de suas palavras próprias, também a busca por qualificar os seus professores/as, para que possam atuar de forma crítica e reflexiva, inclusive através da constituição de suas palavras próprias e apropriadas, contundentes, para ler criticamente o mundo, contar criticamente suas histórias de professor/a, reescrever, historicizar, construir e reinventar sempre o seu ofício. Contudo, para que dê frutos, a reflexão dessa profissional deve ser contínua, sistemática, coletiva, compartilhada, sempre renovada em um diálogo em que entrem a voz de todos - concepçóes, teorias, vozes de professoras, alunos, no fazer responsável e responsivo de todo dia.

E, nesse sentido, reafirma-se também, na cultura docente, a escola e suas práticas como espaço formativo, e o ofício da alfabetizadora como um ofício de muitos fazeres, saberes e de autoria. Como nos lembra Arroyo (2002), o termo "ofício" nos remete a um fazer qualificado, profissional, aos saberes, segredos e as artes de uma profissão.

\section{REFERÊNCIAS}

ARROYO, Miguel Gonzalez. Oficio de mestre: imagens e auto-imagens. Petrópolis: Vozes, 2002.

BAKHTIN, Mikhail M. [VOLOCHÍNOV]. Marxismo e filosofia da linguagem. São Paulo: Hucitec, 1981.

BAKHTIN, Mikhail M. Estética da criação verbal. São Paulo: Martins Fontes, 1994. 
FERREIRO, Emília. Com todas as letras. São Paulo: Cortez, 2001.

FERREIRO, Emília; TEBEROSKY, Ana. Psicogênese da língua escrita. Porto Alegre: Artes Médicas, 1986.

FIORENTINI, Dario; SOUZA JÚNIOR, Arlindo José de; MELO, Gilberto F. Alves de. Saberes Docentes: um desafio para acadêmicos e práticos. In: GERALDI, Corinta M. G., FIORENTINI, Dario; PEREIRA, Elisabete M. A. (Org.). Cartografias do trabalho docente: professor(a) pesquisador(a). Campinas, SP: Mercado das Letras, 1998. p. 307-335.

KLEIMAN, Angela B. (Org.). Os significados do letramento: uma nova perspectiva sobre a prática social da escrita. Campinas, SP: Mercado de Letras, 1995.

NÓVOA, António. Os professores e a sua formação. Portugal: D. Quixote, 1992.

NÓVOA, António (Org.). Vidas de professores. Portugal: Porto, 1995.

PIMENTA, Selma Garrido; LIMA, Maria Socorro Lucena. Estágio e docência. São Paulo: Cortez, 2011.

QUEIRÓS, Bartolomeu Campos de. Ler, escrever e fazer conta de cabeça. São Paulo: Global, 2004.

RIBEIRO, Ana Elisa. Ler na tela: letramento e novos suportes de leitura e escrita. In: COSCARELLI, Carla Viana; RIBEIRO, Ana Elisa (Org.). Letramento digital: aspectos sociais e possibilidades pedagógicas. Belo Horizonte: Autêntica, 2007. p. 125-150.

ROJO, Roxane. Alfabetização e Letramento: perspectivas linguísticas. Campinas, SP: Mercado de Letras, 1998.

ROJO, Roxane. Letramentos múltiplos: escola e inclusão social. São Paulo: Parábola, 2009.

ROJO, Roxane; MOURA, Eduardo. Multiletramentos na escola. São Paulo: Parábola, 2012.

SHÖN, Donald. Formar professores como profissionais reflexivos. In. NÓVOA, António (Org.). Os professores e sua formação. Lisboa: Dom Quixote, 1992. 
SHÖN, Donald. Educando o profissional reflexivo: um novo design para o ensino e a aprendizagem. Porto Alegre: Artmed, 2000.

SOARES, Magda. Letramento: um tema em três gêneros. Belo Horizonte: Autêntica Editora, 2001.

SOARES, Magda. Novas práticas de leitura e escrita: letramento na cibercultura. Educação e Sociedade, Campinas, SP, v. 23, n. 81, p. 143-162, dez. 2002.

SOARES, Magda. A reinvenção da alfabetização. Revista Presença Pedagógica, Belo Horizonte, v. 9, n. 52, jul./ago. 2003 a.

SOARES, Magda. Letramento e alfabetização: as muitas facetas. In: REUNIÃO ANUAL DA ANPED, 26., 2003, Caxambu. Anais... Caxambu, MG: ANPED, 2003b. 1 CD-ROM.

TARDIF, Maurice. Saberes docentes e formação profissional. 8. ed. Rio de Janeiro: Vozes, 2002.

TFOUNI, Leda Verdiani. Letramento e alfabetização. São Paulo: Cortez, 1995.

VYGOTSKY, Lev Semenovitch. A Formação Social da Mente. São Paulo: Martins Fontes, 1984. 


\section{Maestra alfabetizadora: un Literacy teacher: a skill and oficio y muchos quehaceres many practices}

\section{Resumen}

El artículo aborda el oficio de la maestra de alfabetización de los niños - asumiendo el género femenino como predominante en esta actividad - como un oficio que involucra conocimientos relacionados a saberes distintos, teniendo en cuenta los diferentes aspectos del objeto de conocimiento: el lenguaje escrito. En este oficio es importante considerar las concepciones del lenguaje, la enseñanza y el aprendizaje, así como una dimensión cultural más amplia, que permite transitar en el mundo de la literatura, la tradición oral, la cultura del juego de nińos, los diferentes géneros discursivos implicados en las prácticas de lectura y escritura del contexto sociocultural en el que los niños están inseridos, aspectos fundamentales dentro de una concepción de la alfabetización en el contexto de la literacia como ejercicio de las prácticas sociales de la lectura y la escritura y de las múltiples literacias. Finalmente, se articula a ese oficio de muchos quehaceres y saberes a una formación docente reflexiva y crítica que garantice, a las maestras de alfabetización, la autonomía y autoría en su conocimiento y su saber-hacer.

Palabras claves: Alfabetización. Literacia. Formación del profesorado.

\section{Abstract}

The article discusses the profession of literacy teacher of children - assuming the female gender as prevailing in this task- as one that involves knowhow related to different knowledge, considering different aspects of the object of knowledge - the written language. In this profession it is important to consider the language concepts, as well as teaching and learning language and a broader social cultural dimension that allows the teacher to transit into the world of literature, oral tradition, child play culture and the different speech genres which are involved in the reading and writing practices - fundamental aspects in the range of a literacy conception in literacy and multiple literacy contexts. Finally, this literate skill that involves several knowledge and practices, is articulated to a reflective and critical formation of the teacher that ensure to the literacy teachers autonomy and authorship in their knowledge and know-how.

Keywords: Literacy. Literacies. Teacher education. 
Liane Castro de Araujo

E-mail: lica@ufba.br

Mary de Andrade Arapiraca

E-mail:marya@ufba.br

Dinéa Maria Sobral Muniz

E-mail: sobraldm@ufba.br

Enviado em: 4/6/2014

Aprovado em: 24/10/2014 